\title{
Biocompatibility of Polyhydroxybutyrate Microspheres: in vitro and in vivo Evaluation
}

\author{
Ekaterina I. Shishatskaya ${ }^{a *}$, Olga N. Voinova ${ }^{a}$, \\ Anastasya V. Goreva ${ }^{a}$, Olga A. Mogilnaya ${ }^{a}$ and Tatiana G. Volova ${ }^{a, b}$ \\ ${ }^{a}$ Institute of Biophysics of Siberian Branch of Russian Academy of Sciences, \\ Akademgorodok, Krasnoyarsk, 660036 Russia \\ ${ }^{b}$ Siberian Federal University, \\ Svobodny av.79, Krasnoyarsk, 660041 Russia $^{1}$
}

Received 1.09.2007, received in revised form 1.12.2007, accepted 15.01.2008

Microspheres have been prepared from the resorbable linear polyester of $\beta$-hydroxybutyric acid (polyhydroxybutyrate, $P H B$ ) by the solvent evaporation technique and investigated in vitro and in vivo. Biocompatibility of the microspheres has been proved in tests in the culture of mouse fibroblast cell line NIH $3 T 3$ and in experiments on intramuscular implantation of the microspheres to Wistar rats for 3 months. Tissue response to the implantation of polymeric microspheres has been found to consist in a mild inflammatory reaction, pronounced macrophage infiltration that increases over time, involving mono- and poly-nuclear foreign body giant cells that resorb the polymeric matrix. No fibrous capsules were formed around polymeric microparticles; neither necrosis nor any other adverse morphological changes and tissue transformation in response to the implantation of the PHB microparticles were recorded. The results of the study suggest that polyhydroxybutyrate is a good candidate for fabricating prolonged-action drugs in the form of microparticles intended for intramuscular injection.

Keywords: microencapsulation; resorbable polymers; polyhydroxybutyrate; cytotoxicity; tissue response.

\section{Introduction}

Designing of controlled-release drug delivery systems is a promising and rapidly developing line of pharmacology. The main advantage of using drug delivery systems is that drug concentration in a patient's blood and/or tissues can be maintained at a target level for an extended time (Amass et al., 1998; Kost and Langer, 2001). The most promising drug delivery systems seem to be biodegradable microspheres and microcapsules, which can be used to deliver a wide range of drugs; they can be injected into the bloodstream, subcutaneously, and intramuscularly and adapted for oral administration or inhalation (Freiberg and Zhu, 2004). The principal requirement for fabricating prolonged-action controlled-release drug delivery systems is availability of an appropriate material, which must be absolutely harmless to an organism and possess the necessary physical-mechanical and biomedical properties, including degradability in biological media. At the present time, the most widely used and actively

\footnotetext{
Corresponding author E-mail address: shishatskaya@inbox.ru (c) Siberian Federal University. All rights reserved
} 
developed bioresorbable materials are polymers of monocarboxylic acid derivatives (polylactides and polyglycolactides), which have recently been joined by linear polyesters of microbiological origin - polyhydroxyalkanoates (PHAs) (Amass et al., 1998; S. Williams and Martin, 2002).

It has been shown that PHAs can be used to fabricate various items for medicine: surgery, transplantology, tissue engineering, and pharmacology (Anderson, 1988, 1997). One of the main tasks facing those investigating new biomaterials is to prove that they are absolutely biocompatible with and harmless to the host organism. Some researchers investigating PHAs such as polyhydroxybutyrate (PHB) and hydroxybutyrate/hydroxyvalerate copolymers (PHB/PHV) reported their cytotoxicity in animal cell cultures in vitro (Freiberg and Zhu, 2004) and slight inflammatory and pyrogenic reactions in animals during in vivo experiments (Gogolewski et al., 1993b). In recent years in vivo studies were conducted to evaluate biocompatibility of new PHAs (incorporating hydroxyhexanoate) (Qu et al., 2006). However, inflammation and other undesirable reactions to the tested biomaterials can also be related to their chemical composition, a particular implantation site, and the degree of chemical purity of the material.

Literature reports show that it is not uncommon to use commercially availablepolymers in biomedical studies of PHAs (Williams et al., 1999). The level of endotoxins in them can reach 120 U/g (Sadian et al., 2000; Sevastianov et al., 1990) due to the presence of microbial cell debris, which contains lipopolysaccharides and other complexes capable of causing negative reactions in cells in the in vitro systems and pyrogenic reactions in vivo (Sevastianov, 1990; Dobrova et al.,1991). We have developed a procedure for synthesis, recovery and purification of PHAs to prepare polymer specimens that would not contain organic impurities of protein, carbohydrate or lipid nature. Experiments with two PHA types - polyhydroxybutyrate (PHB) and copolymers of hydroxybutyric and hydroxyvaleric acids (PHBV) - in cultures of animal cells of various origins (fibroblasts, hepatocytes, and endothelial cells) did not show any negative influence of these PHAs, which directly contacted the cultured cells, on the cells. In experiments with laboratory animals biocompatibility of these polymers was proven at the cell (Stasishina avd Volova, 1996), tissue (Volova and Kalacheva, 1996a), and organism (Volova et al., 1996b) levels.

The biocompatibility of polyhydroxybutyrate (PHB, the most widespread and best studied PHA) has been confirmed in vitro, in cultures of cells of various origins (Volova, 2004; Saad et al., 2000; Shishatskaya et al., 2004a). Rather few results have been reported on in vivo biocompatibility of PHB, including data on local tissue reaction to polyhydroxybutyrate and poly(hydroxybutyrate/ hydroxyvalerate) implants (Gogolewski et al., 1993b; Shishatskaya and Volova, 2004b). However, those investigations were performed using large implants, in the form of sutures, film grafts or pins (Williams and Martin, 2002; Qu et al., 2006). It is well-known, though, that biocompatibility of biomaterials depends not only on the chemical structure and purity of the specimens but, to a large extent, on the size and shape of the implant (Anderson and Shive, 1997).

Microspheres are considered to be the best form for injection-delivered prolonged-action drugs. However, microspheres, though containing a small amount of biomaterial, have a large surface area and, being injected subcutaneously or intramuscularly, come in contact with extensive area inside the host organism, which can cause stronger tissue reaction (Anderson and Shive, 1997; Vospaleniye, 1995).

The purpose of this study was to test polyhydroxybutyrate microparticles for 
cytotoxicity in vitro, in fibroblast culture, and to investigate tissue response to intramuscular implantation of PHB in vivo.

\section{Materials and methods}

\subsection{Preparation of pure PHB polymer}

The tested material was the PHB samples synthesized by the bacterium Ralstonia eutropha B5786 ( $\mathrm{M}_{\mathrm{w}} 340000 \mathrm{Da}$, crystallinity 70-78\%). The strain is registered in the Russian Collection of Industrial Microorganisms. The culture technique was described elsewhere (Volova and Kalacheva, 1996a). PHB is extractable from bacterial biomass due to its ability to dissolve in organic solvents and to be then precipitated by alcohols. PHB was extracted from bacterial biomass with chloroform and precipitated with ethanol. The extraction of PHB from biomass was conducted in several stages. In the first stage, to partially destroy the cell wall and attain a fuller extraction of lipids, the bacterial biomass was centrifuged (for $15 \mathrm{~min}$ at $6000 \mathrm{rpm}$ ), collected, and covered with ethanol, $\mathrm{pH}$ 10.5-11.0 (0.5-0.7 g KOH/L ethanol). The sample was boiled using a backflow condenser for $30 \mathrm{~min}$. Then the alcohol was removed, the biomass was covered with $86 \%$ ethanol and separated from alcohol by centrifuging. In the next stage the partly destroyed and defatted biomass was covered with chloroform and boiled for 30-40 min using a water bath with a backflow condenser. The sample was cooled and placed into a funnel to separate the chloroform extract of the polymer from the biomass. After separation of the phases, the polymer was precipitated by adding ethanol as a reagent. The procedure of redissolution and further precipitation of polymer was repeated several times to prepare specimens that would not contain organic impurities of protein, carbohydrate or lipid nature. All the organic solvents used in the procedure were preliminarily distilled to remove impurities. We have previously shown that this procedure can be used to prepare high-purity PHB specimens, which would not contain any organic impurities - components of bacterial biomass - and would exhibit excellent biocompatibility characteristics, allowing them to contact blood (Sevastianov et al., 2003). The trademark of the material is Bioplastotan (Trademark "BIOPLASTOTAN". Registration Certificate № 315652).

\subsection{Preparation of microspheres}

PHA-based microspheres were prepared by the solvent evaporation technique, using a triple emulsion. $600 \mathrm{mg}$ of the polymer (PHB) and $200 \mathrm{mg}$ of polyethylene glycol (PEG40, molecular mass $40 \mathrm{kDa}$ ) were dissolved in $10 \mathrm{ml}$ of dichloromethane at $40^{\circ} \mathrm{C}$. Then, $1 \mathrm{ml}$ of a $6 \%$ gelatin solution $\left(40^{\circ} \mathrm{C}\right)$ was added and the mixture was shaken vigorously. The resulting water/oil (W/ O) double emulsion was allowed to cool to room temperature and, then, it was gradually poured into $150 \mathrm{ml}$ of a $0.5 \%$ PVA solution, which was stirred with a three-blade propeller (at $700 \mathrm{rpm}$, for $20 \mathrm{~min}$ ), to obtain a triple (water/oil/water, W/ $\mathrm{O} / \mathrm{W}$ ) emulsion. The emulsion was continuously mixed mechanically for $24 \mathrm{~h}$, until the solvent was completely evaporated. Microspheres were collected by centrifuging (at $10000 \mathrm{rpm}$, for 5 $\mathrm{min}$ ), rinsed 7-8 times in distilled water, and freeze dried in an LS-500 lyophilic dryer (Russia).

\subsection{Microspheres characterization}

The size (number and volume weight mean diameter) and the size distribution of microspheres suspended in water were determined with an optical particle sizer Particle counter CASY TTC (Scharle system GmbH, Germany). Water was used as eluent. The microstructure of film surfaces was analyzed by electron microscopy. The samples were placed on the microscopic stage, coated with carbon and aluminum in a JEE4C vacuum evaporator and studied using a JEM- 
100C electron microscope with an EM-ASID-4 raster attachment (Japan).

\subsection{In vitro cytotoxicity of microspheres}

After sterilization, microspheres were tested for cytotoxicity towards the growth, morphology and metabolism of fibroblasts. The cytotoxicity test was conducted according to the ISO 10993 standard. MEM Elution-Test on Extracts was conducted according to the ISO 10993-5 standard: in this study, $100 \mathrm{mg}$ of the dry microspheres (equals at least $120 \mathrm{~cm}^{2}$ ) were extracted at $37^{\circ} \mathrm{C}$ for $24 \mathrm{~h}$ in $20 \mathrm{ml}$ Minimum essential Medium (MEM) supplemented with $10 \%$ fetal calf serum. $60 \mathrm{~cm}^{2}$ of industrial red rubber extract was a positive control; $60 \mathrm{~cm}^{2}$ of polystyrene "Greiner bio-one" was used as a negative control. An extract was prepared from the test material, which was then placed on cell monolayers. The cells were examined for morphologic changes and cytolysis to determine a toxicity score. The objects used were cultured cells: mouse fibroblast cell line NIH 3T3, which belongs to the least transformed cell lines and retains many features of normal diploid cells. Fibroblasts of line NIH 3T3 were cultured in DMEM medium supplemented with 10\% FCS (RPA “Vector", Novosibirsk), 1.0 $\mathrm{mM}$ L-glutamine, $10 \mathrm{mM}$ HEPES, and $100 \mu \mathrm{g} /$ $\mathrm{ml}$ kanamycin sulfate (BDSL, UK). Cells were cultured in a humidified atmosphere at $5 \% \mathrm{CO}_{2}$ at $37^{\circ} \mathrm{C}$. The duration of experiments ranged from $4 \mathrm{~h}$ to 3 days. The cell count increased after the cells were passed two or three times using $0.2 \%$ collagenase solution diluted with a $0.02 \%$ versene solution. All stages were conducted under sterile conditions. After exposure to the extract for $72 \mathrm{~h}$ at $37^{\circ} \mathrm{C}$ the medium was removed, leaving a film of medium in each well, and the cells were examined and scored microscopically for cytotoxic effects: confluency of the monolayer and change of cellular morphology.
For cytological investigations, fixed and incompletely dried cells were Giemsa stained in a standard Jurr 65500 buffer at $\mathrm{pH} 6.8$ and examined under a microscope with an H190/1.30 immersion objective and a PKIOX ocular. Preliminarily, cell viability was estimated by live staining with trypan blue $(0.5 \%$ stain solution in $0.85 \% \mathrm{NaCl})$. Cell proliferation was measured at 3 days using 3-(4,5dimethylthiazol-2-yl)-2,5-diphenyl tetrazolium bromide (MTT) assay (Freshney, 2000). $800 \mu 1$ serum free medium and $80 \mu \mathrm{l}$ MTT solution (5 mg MTT/ml in phosphate buffer saline) were quickly added to each sample and incubated for 3 $\mathrm{h}$ at $37^{\circ} \mathrm{C}$ until formazan crystals were formed in cells. The medium and MTT were replaced by 800 $\mu 110 \%$ sodium dodecyl sulfate (SDS) in $0.01 \mathrm{M}$ $\mathrm{HCl}$ to dissolve the formazan crystals. Formazan concentrations were quantitatively determined by measuring the optical density (OD) at $570 \mathrm{~nm}$ against SDS solution blank. Each sample was measured thrice. The number of living cells in the culture was determined from the MTT absorbance standard curve.

\subsection{Animal model}

In vivo experiments were conducted on sexually mature female Wistar rats (200-240 g each). The rats were kept in a vivarium and fed a standard diet in accordance with the directive "Using animals in space biology and medical studies" (Genin et al., 2001). As control, intact animals were used.

Sterile microspheres $(20 \mathrm{mg}$ in $0.3 \mathrm{ml}$ of a physiological saline) were injected intramuscularly into the femurs of the rats. At $24 \mathrm{~h}$ after injection and then every week, three animals were sacrificed by using an overdose of diethyl ether as volatile anesthetic.

The general tissue reaction to implanted microspheres was investigated using conventional histological techniques. The microspheres were removed with excess surrounding tissue; the 
samples were fixed in $10 \%$ formalin and embedded in paraffin; 5-10 $\mu \mathrm{m}$ thick microtome sections were stained with hematoxylin and eosin.

To prepare semithin sections, tissue samples were fixed in $2.5 \%$ glutaraldehyde in $0.1 \mathrm{M}$ cacodylate buffer at $\mathrm{pH} 7.2$; then they were additionally fixed in a $1 \% \mathrm{OsO}_{4}$ solution in the same buffer. The samples were dehydrated in graded series of ethanol and in acetone; then they were embedded in Epon 812-Araldite M resin ("Serva"). Semithin (1.5 $\mu$ m thick) sections were cut using a Reichert Um-03 ultramicrotome (Austria) and then stained with $1 \%$ methylene blue. A Carl Zeiss Image Analysis System (Germany) was used for viewing microscopic images and analyzing morphometric characteristics of sections (ocular 10, objectives 10 and 40). The slides were evaluated for intensity and duration of inflammation, infiltration of cells at the site of microspheres injection, and the state of implanted microspheres. Assessment of the activity of cell elements was based on their average number in the field of view, with 10 fields of view analyzed.

\subsection{Statistics}

All measurements in the in vitro tests were made at least in 2 experiments. Statistical analysis of the results was made using the standard software package of Microsoft Excel. Arithmetic means and standard deviations were found. Significant differences between mean values in control and treatment groups were tested using Student's t test (significance level: $\mathrm{p}=0.05$ ) by standard methods.

\section{Results and Discussion}

\subsection{Microspheres characterization}

The microspheres were of regular spherical shape and had a well-developed "wrinkled" porous surface; their diameters were significantly heterogeneous (Fig. 1). The size distribution of the microspheres injected intramuscularly in the rats was as follows (Fig. 2). The fraction of the microspheres of diameter up to $2 \mu \mathrm{m}$ amounted to $33.3 \pm 2.2 \%$. Microspheres of this size are considered to be the best for injections (Dijkhuizen-Radersma et al., 2002). The fraction of the particles 2 to $10 \mu \mathrm{m}$ in diameter constituted $38 \pm 1.9 \%$ and the fraction of the particles larger than $10 \mu \mathrm{m}-29 \pm 2.3 \%$. The largest of the harvested particles were of diameter $35 \mu \mathrm{m}$ and their fraction did not exceed 3-5\%. The microparticles used in the experiment were of mean diameter $10 \mu \mathrm{m}$ and of volume $0.016 \mathrm{~cm}^{3}$.

\subsection{Cytotoxity}

Evaluations of growth and metabolic parameters of the fibroblast cell culture in the treatment group and in the positive and negative control groups are presented in the table.Mouse fibroblast cells (NIH 3T3 line) cultured in the presence of polymeric (PHB) microspheres extracts similarly to the negative control
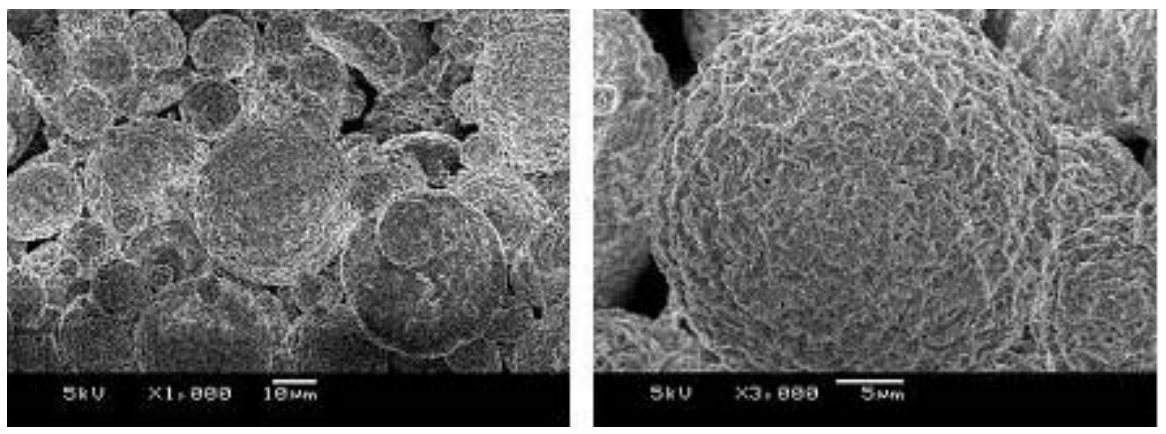

Fig. 1. Micrographs of the microspheres prepared from polyhydroxybutyrate. 


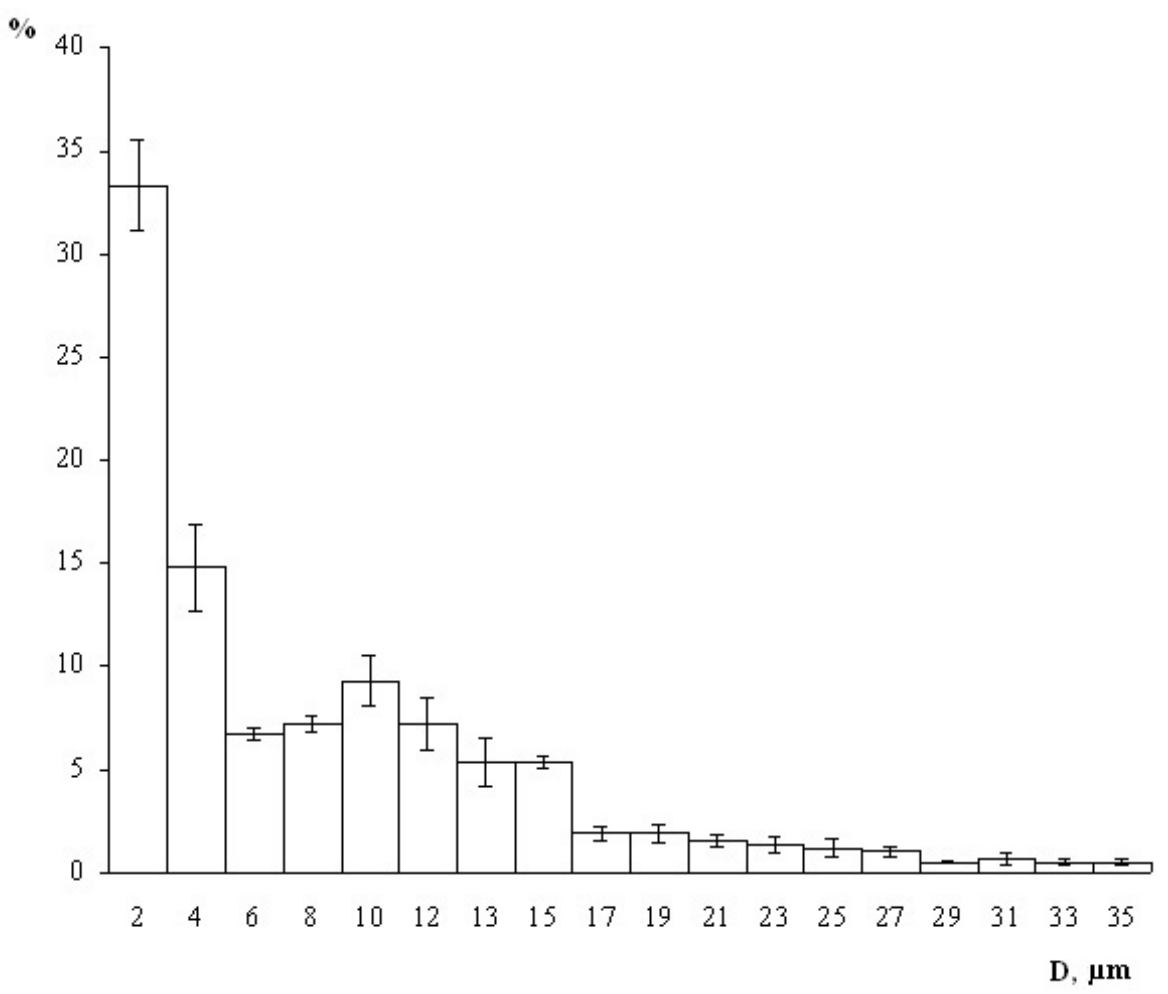

Fig. 2. The size distribution of the microspheres injected intramuscularly in the rats

(polystyrene extract) retained the morphology of normal cells, like those grown in the control, on polystyrene. Cell viability test, performed by the method of live staining with trypan blue, showed that $99.8 \pm 0.2 \%$ of the cultured cells did not incorporate the dye, i.e. remained highly viable, in contrast to the positive control (rubber extract), in which most of the cells died (table).

The doubling time of fibroblasts corresponded to the generation time of the cells cultured on standard medium and experimental culture were $25.1 \pm 1.8$ and $25 \pm 2 \mathrm{~h}$; on negative and positive controls $-24.9 \pm 2.1$ and $168 \pm 21.3$ The MTT test did not indicate any toxic effect of the polymer extract on the metabolic activity of fibroblasts, either. Cell concentration of the experimental culture was comparable to those of the negative control and the standard medium culture (190 \pm 23 $\times 10^{6}$ ), and that was almost an order of magnitude higher than in the positive control $\left(200 \pm 24 \times 10^{5}\right)$.
It is well-known that only active dehydrogenases of living cells will convert MTT into insoluble formazan crystals.

Our investigations showed that extracts of polymeric PHB microparticles did not produce any toxic effect on proliferation and metabolic activity of mouse fibroblast cell line NIH 3T3. The biocompatibility of the polymeric microparticles was subsequently investigated in the long-duration in vivo experiment.

\subsection{In vivo reaction}

All animals in the treatment group, which had been injected with a microspheres suspension, were healthy and ate well. Their body mass and masses of their internal organs were similar to those of the rats in the control group.

At $24 \mathrm{~h}$ after the injection of polymeric microparticles, the microscopic picture at the injection site was characterized by a slight tissue 
edema and leukocyte infiltration. The cluster of microspheres injected intramuscularly may be considered as an open porous implant.

The nature and extent of the tissue reaction to the implant is known (Anderson and Shive, 1997; Serov, 1995) to be characterized by the presence of specific cell types. After injury due to surgical intervention and implantation of the material or a tested item, aseptic tissue inflammation develops at the site of implantation. It is usually divided into several phases: alteration (injury), exudation, and proliferation; the last phase is at the same time the first phase of tissue repair. The phases of exudation and proliferation are sometimes subdivided into neutrophil, macrophage, and fibroblast phases. The neutrophil phase occurs during the first few hours of implantation: polymorphonuclear leukocytes (PMNs) migrate from the vessels to the site of damage, surround it, and, after 6-12 h, form a leukocyte barrier. The lifetime of PMNs is short; within $24 \mathrm{~h}$ neutrophilic leukocytes stop migrating and their decomposition is started.

In our experiment, in $24 \mathrm{~h}$ after the injection of PHB microparticles, the initial inflammatory response was started as could be seen from the presence of polymorphonuclear leukocytes (up to 20-25 in the field of view). This tissue reaction was of short duration; after 1 week the intensity of polymorphonuclear leukocytes decreased significantly. The low intensity of leukocytes during that time suggests that tissue reaction to the implantation of polymeric microparticles can be described as a mild inflammatory response. After 1 week of implantation, we observed infiltration of fibroblast cell elements and formation of a thin fibrous capsule at the interface between the microspheres and the intact muscular tissue, as a foreign body reaction of the tissue.

The foreign body reaction is expressed by the amount of macrophages at the microspheres/tissue interface (Anderson and Shive, 1997). In this phase (the macrophage phase), macrophages penetrate into the leukocyte barrier and phagocytize cell detritus and degradation products from the tissue and implanted material. Macrophages surround the foreign body and form neutrophil-macrophage $\rightarrow$ macrophage $\rightarrow$ macrophage-fibroblast barriers, which prevents the formation of granulation tissue (Marchant et al., 1983; Zhao et al., 1992; Kao et al., 1994). When biodegradable materials are implanted, the macrophage response, which follows the neutrophil response, increases rather than decreases. The reason for this is that macrophages and foreign body giant cells phagocytize and resorb biodegradable materials. The main contribution to the formation of foreign body giant cells (FBGCs) is made by macrophages, which phagocytize the implanted material. It is well-known that FBGCs, formed on the surface of or around the particles of the implanted material by the fusion of macrophages and by nuclear division of macrophages without cytokinesis, resorb the material (Khrushchev et al., 1978; Rhee et al., 1979; Anderson, 2001). This has been demonstrated in numerous studies of polymeric microparticles prepared from various resorbable materials: polyethylene glycol (DijkhuizenRadersma et al., 2002), polylactides and lactide/ glycolide copolymers (Kang and Singh, 2005), and poly(methylidene malonate 2.1.2 (Fournier, et al., 2006).

It has been reported that in some PHAs, including 3- and 4-polyhydroxybutyrate, in vivo resorption involves active participation of phagocytic macrophages and foreign body giant cells (FBGCs) (Williams and Martin, 2002). In our recent study we investigated tissue response to polyhydroxybutyrate monofilament sutures used to close muscle-fascial wounds and found out that macrophages played an important role in the tissue repair response, phagocytizing injured cells and tissues and polymer particles and degradation products (Shishatskaya et al., 2004a). The reaction of tissues to polyhydroxybutyrate 
implants was comparable in intensity and length to their reaction to silk and was considerably less pronounced than their reaction to resorbable catgut.

Figure 3 shows the tissue at the microspheres implantation site at 2 weeks. One can see mononuclear secretory-phagocytic macrophages and a few FBGCs with 2-3 nuclei.

Besides phagocytosis, macrophages initiate the formation of granulation tissue. The granulation tissue response is characterized by fibroblast infiltration and the development of blood capillaries (Anderson, 1988). If an implant is made from non-resorbable material, a thick fibrous capsule is usually formed around it. If biocompatible and biodegradable implants are used, the tissue response may not involve the formation of a thick fibrous capsule or, if the capsule is formed, it is later involuted (Shishatskaya et al., 2004a). At 2 weeks, the cluster of the injected microspheres was encapsulated with thin connective tissue (Fig. 3). At that time,

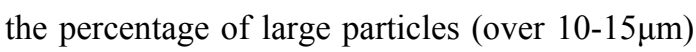
in the cluster of microspheres was significantly reduced and did not exceed $14 \%$ in the field of view. Active fibroblast elements were identified in the structure of the thin capsule; its mean thickness was not more than 50-60 $\mu \mathrm{m}$; it consisted of 4-6 fibroblast layers. The reaction was almost 3 times less intensive than the reaction of muscular tissue to the implantation of sutures that we reported earlier (Shishatskaya et al., 2004a). This result is in good agreement with the data reported by Fournier et al. (Fournier et al., 2006), who found that the intramuscularly injected microspheres cluster was isolated from the muscular tissue by a very thin fibrous capsule, which was much less developed than the capsule formed in the event of subcutaneous injection. At the site of injection of PHB microparticles, the newly formed tissue was significantly vascularized, indicating high biocompatibility of the polymeric microspheres and favorable tissue reaction. The area of the edema at the implantation site was considerably decreased, there were no necrotic areas. There were a few leukocytes among the microspheres. We recorded an increase in the number of mature secretory-phagocytic macrophages (up to $6.36 \pm 0.42$ in the field of view) on the inner side of the capsule adhering to the implant and at the cluster of the microspheres.

Later in the experiment we observed more intensive macrophage infiltration at the site of injection of the microspheres; the amounts of both

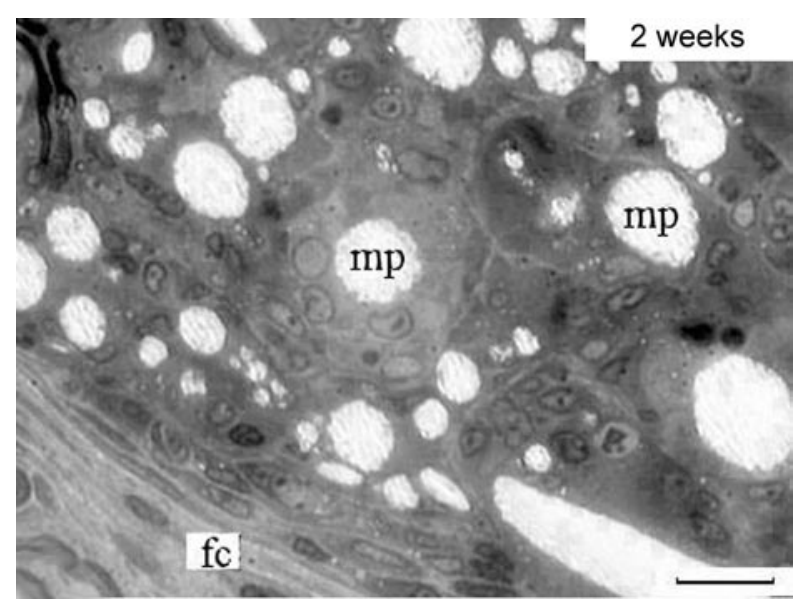

Fig. 3. Microscopic picture of tissue at the site of polyhydroxybutyrate microspheres implantation ( 2 weeks after implantation). Mp stands for microparticles, fc - fibrous capsule. The bar is $20 \mu \mathrm{m}$ 
mononuclear macrophages and FBGCs increased. At 5 weeks, the number of mono- and polynuclear macrophages at the site of implantation of the microspheres increased (Fig. 4a). The fraction of large particles became smaller and did not exceed $4-5 \%$ of the total amount of the particles in the field of view, suggesting that the polymeric matrix was being degraded. FBGCs with 6-8 nuclei were observed to aggregate around large (more than $10 \mu \mathrm{m}$ in diameter) microspheres. At the interface between the intact muscular tissue and the microspheres there still was a fibrous capsule, though very thin, consisting of 2-3 layers of mature fibroblasts (Fig. 4b). The macrophage response grew more intense at 7-9 weeks; the number of FBGCs increased and so did the number of their nuclei. At the site of implantation of the microspheres we clearly saw macrophages grouped around large microparticles. In some cases we could see penetration of cell elements into the surface matrix of the microspheres and degraded (resorbed) parts around the circumference of the particles at the implant/tissue interface (Fig. 5a), which indicated that the polymeric matrix of the microparticles was being degraded. There were no fibrous capsules either at the microspheres/tissue interface or around any of the microspheres. This is a very important fact because the fibrous capsule around a polymeric particle could significantly influence the release behavior of the encapsulated drug and resorption of the polymeric matrix.

At the end of the experiment (11-12 weeks), the tissue reaction remained essentially the same: we observed pronounced macrophage infiltration with a large number of poly-nuclear FBGCs, which either surrounded polymeric particles or were grouped around a cluster of smaller microparticles; there were rather large fusions of FBGCs with 10-12 and even more nuclei (Fig. 5a). There were no fibrous capsules at the interface between the intact muscular tissue and the cluster of the microspheres. In some parts of the microspheres cluster there was polymeric detritus, as a degradation product of larger particles. The fraction of microspheres larger than 10-15 $\mu \mathrm{m}$ in the field of view significantly decreased (to about 2-3\%) and fragmented microparticles were seen (Fig. 5b). For quite a long time, however, most of the microspheres persisted in the tissue undegraded, suggesting that in vivo bioresorption of microparticles must be rather a long process, which makes polyhydroxybutyrate a good candidate for fabricating a prolonged-action drug form intended for intramuscular injection.

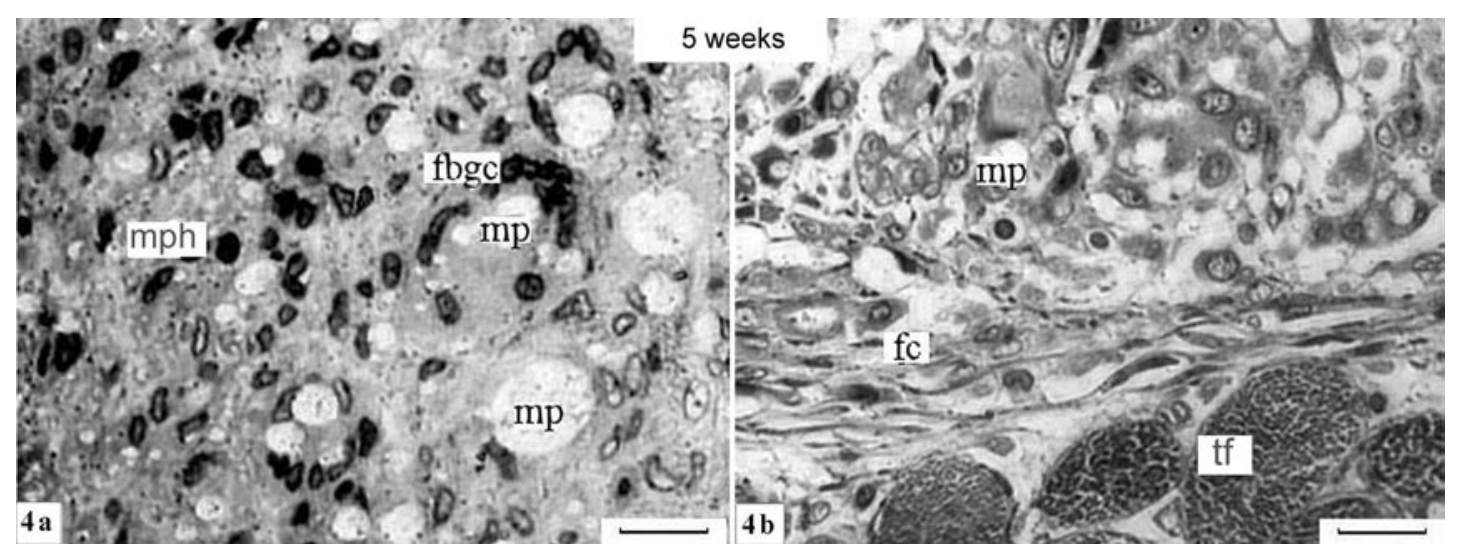

Fig. 4. Microscopic picture of tissue at the site of polyhydroxybutyrate microspheres implantation ( 5 weeks after implantation). Mp stands for microparticles, $\mathrm{mph}-$ macrophages,

FBGCs - foreign body giant cells, tf - tissue fibers, fc - fibrous capsule. The bar is $20 \mu \mathrm{m}$ 

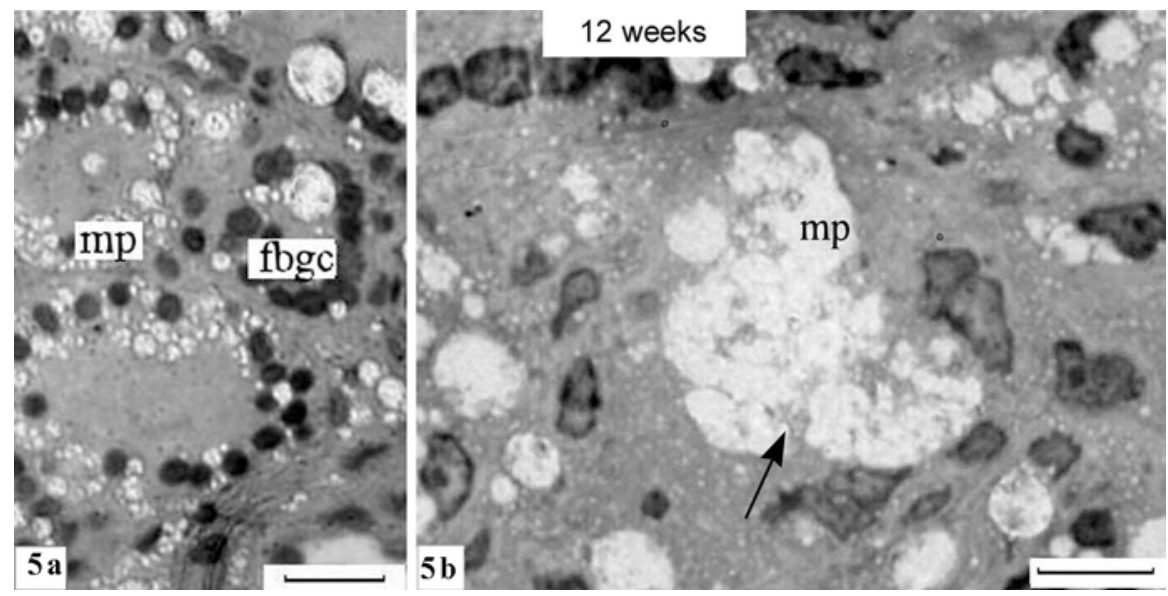

Fig. 5. Histology of the in vivo degrading microspheres implanted intramuscularly, at 12 weeks.

The bar is $10 \mu \mathrm{m}$

\section{Conclusion}

In vitro and in vivo experiments showed that polyhydroxybutyrate microspheres of diameter from 0.9 to $35.0 \mu \mathrm{m}$ were biocompatible; they neither inhibited growth and metabolic activity of fibroblasts nor caused negative response in animals that were intramuscularly injected with them. The tissue response to the implantation of polyhydroxybutyrate microparticles was characterized by mild inflammatory reaction of short duration, pronounced and ever increasing macrophage infiltration involving foreign body giant cells that resorbed the polymeric matrix, and the granulation response, involving the formation of a highly vascularized thin fibrous capsule at the microspheres/tissue interface, which was resorbed after several weeks of implantation. No fibrous capsules were formed around polymeric microparticles; neither necrosis nor any other adverse morphological changes and tissue transformation in response to the implantation of the polymeric microparticles were recorded. The results of the study suggest that polyhydroxybutyrate is a good candidate for fabricating prolonged-action drugs in the form of microparticles intended for intramuscular injection.

\section{Acknowledgments}

This study was financially supported by the Russian Ministry of Education and the U.S. Civilian Research \& Development Foundation CRDF (Grant No. P1MO002), the Program of the RAS Presidium "Fundamental Research to Medicine" (Project No. 12.5), and the Program of the President of Russia (Grant MK-4149.2006.4).

\section{References}

Amass W., Amass A., Tighe B. (1998) A review of biodegradable polymers: uses, current developments in the synthesis and characterization of biodegradable polyesters, blends of biodegradable polymers and recent advances in biodegradation studies. Polymer Int. 47:89-144.

Anderson J.M. (1988) Inflammatory response to implants. ASAIO 11:101-6.

Anderson J.M., Shive M.S. (1997) Biodegradation and biocompatibility of PLA and PLGA microspheres. Adv. Drug. Deliv. Rev. 28:5-24. 
Anderson J.M. (2001) Biodegradation of polymers. In: Buschow K.H.J., Cahn R., Fleming M.C., Ilschner B., Kramer E.J., Mahajan S., Veyssiere P. (eds) Encyclopedia of Materials: Science and Technology, Pergamon, London, p.560-563.

Dijkhuizen-Radersma R., Hesseling S.C., Kaim P.E. (2002) Biocompatibility and degradation of poly(ether-ester) microspheres: in vitro and in vivo evaluation. Biomaterials 23:4719-29.

Dobrova N.B., Noskova T.P., Novikova S.P., Sevastianov V.I. (1991) Sbornik metodicheskikh rekomendatsii po otsenke biosovmestimykh svoistv iskusstvennykh materialov, kontaktiruyushchikh $\mathrm{s}$ krovyyu (Collected methodological suggestions for evaluating biocompatible properties of artificial materials contacting blood). VNITIPRIBOR, Moscow, 70 p. (in Russian).

Fournier E., Passirani C., Colin N., Sagodira S., Menei P., Benoit J.P., Montero-Menei C. (2006) The brain tissue response to biodegradable poly(methylidene malonate 2.1.2)-based microspheres in the rat. Biomaterials 27: 4963-4974.

Freiberg S., Zhu X. (2004) Polymer microspheres for controlled drug release. Int. J. Pharm. 282: $1-18$.

Freshney R.I. (2000).Culture of animal cells: a manual of basic technique, $4^{\text {th }}$ ed. New York, USA: Wiley, 329, Chapter 21.

Genin A.M., Il 'in A.E., Kaplanskii A.S., Kasatkina T.B., Kuznetsova K.A., Pestov I.D., Smirnova T.A. (2001) Bioeticheskie pravila provedeniya issledovanii na cheloveke i zhivotnykh v aviatsionnoi, kosmicheskoi i morskoi meditsine (Bioethical rules of realization of investigations on a man and animals in aviation, space and marine medicine). Aviakosmicheskaya i ekologicheskaya meditsina 35(4): 1420. (in Russian).

Gogolewski S., Javanovic M., Perren S.M., Dillon J.G., Hughes M.K. (1993) Tissue response and in vivo degradation of selected polyhydroxyacids: polylactides (PLA), poly(3-hydroxybutyrate) (PHB), and poly(3-hydroxybutyrate-co-3-hydroxyvalerates (PHB/PHV). J. Biomed. Material Res. 27:1135-1148

Kao W.J., Zhao Q.H., Hiltner A., Anderson J.M. (1994) Theoretical analysis of in vivo macrophage adhesion and foreign body giant cells formation on polydimethylsiloxane, low density polyethylene and polyetherurethane. J. Biomed. Material Res. 28:73-79.

Kang F., Singh J. (2005) Preparation, in vitro release, in vivo absorption and biocompatibility studies of insulin-loaded microspheres in rabbits. AAPS Pharm. Sci. Tech. 6(3):487-94.

Kost J., Langer R. (2001) Responsive polymeric delivery systems. Adv. Drug. Deliv. Rev. 46: $125-48$.

Khrushchev N.G., Lange M.A., Satdykova G.N. (1978) Autoradiographic electron microscopy of foreign body giant cells at the site of aseptic inflammation. Arkh. Anatomii (Anatomy Archives) No.8: 43-50 (in Russian).

Marchant R., Hiltner A., Hamlin C., Rabinovitch A., Slobodkin R., Anderson J.M. (1983) In vivo biocompatibility studies. 1.The cage implant system and biodegradable hydrogel. J. Biomed. Material Res. 17: 301-325.

Qu X., Wu Q., Zhang K., Chen G.Q. (2006) In vivo studies of poly(3-hydroxybutyrate-co-3hydroxyhexanoate) based polymers: biodegradation and tissue reactions. Biomaterials 27:3540-8.

Rhee H.J., Birgh-DeWinter S.D.M., Dafms W.H. (1979) The differentiation of monocyte into macrophages, epithelioid cells in subcutaneous granulomass. Cell Tis Res.198: 355-78. 
Saad B., Casotti M., Huber Th., Schmutz P., Welti M., Uhlschmid G.K. Neuenschwander P.; Suter UW. (2000) In vitro evaluation of the biofunctionality of osteoblasts culture on Degra-Polyfoam. J. Biomater. Sci. Polymer. Edn. 11(8): 787-800.

Sadian R., Hoerstrup S.P., Sperling J.S., Daebritz S.H., Martin D.P., Schoen F.J., Vacanti J.P., Mayer J.E.Jr. (2000) Tissue engineering of heart valves: in vitro experiences. The Annals of Thoracic Surgery 70: 140-144.

Sevastianov V.I., Rozanova I.B., Tseitlina E.A., Khazen L.Z., Gorshov A.V., Kornienko G.N., Eberkhart R., MacMillen K. (1990) An in vitro methodology of selecting hemocompatible biomaterials for artificial organs. Meditsinskaya tekhnika (Medical technology) 4: 26-29 (in Russian).

Sevastianov V.I. (1990) Biomaterials for artificial organs Iskusstvennyye organy (Artificial organs). In: Shumakov V.I., (ed.) Meditsina, Moscow, p. 216 (in Russian).

Sevastianov V.I., Perova N.V., Shishatskaya E.I., Kalacheva G.S.; Volova T.G. (2003) Production of purified polyhydroxyalkanoates (PHAs) for applications in contact with blood. J Biomater. Sci. Polymer Edn. 14 (10): 1029-42.

Shishatskaya E.I., Volova T.G., Efremov S.N., Puzyr A.P., Mogilnaya O.A. (2004a) Tissue response to the implantation of biodegradable polyhydroxyalkanoate sutures. J. of Material Science: Materials in medicine 15(6): 719-28.

Shishatskaya E.I., Volova T.G. (2004b) A comparative investigation of biodegradable polyhydroxyalkanoate films as matrices for in vitro cell cultures. J. Material Science: Materials in Medicine 15(8): 915-923.

Stasishina G.N., Volova T.G. (1996) Shtamm bakterii Alcaligenes eutrophus B5786- produtsent... (The producing strain of the bacterium Alcaligenes eutrophus B5786) / RF Patent No. 2053292 (in Russian) № 1 .

Trademark "BIOPLASTOTAN"TM". Registration Certificate No. 315652 of the Federal Institute for Patent Examination for Application No. 2006703271/50.

Williams S.F., Martin D.P. (2002) Applications of PHAs in medicine and pharmacy. In: Steinbüchel A, ed. Series of Biopolymers in 10 vol. Wiley-VCY Verlag GmbH, 4: 91-121.

Williams S.F., Martin D.P., Horowitz D.M., Peoples O.P. (1999) PHA application: addressing the price performance issue. I. Tissue engineerin. Int. J. of Biol. Macromol. 235: 111-21.

Volova T.G., Kalacheva G.S. (1996a) Sposob polucheniya polimera $\beta$-oksimaslyanoi kisloty (A technique of producing a polymer of $\beta$-hydroxybutyric acid). / RF Patent No. 2051967. (in Russian) №3.

Volova T.G., Kalacheva G.S., Konstantinova V.M. (1996b) Sposob polucheniya geteropolimerov 3-oksimaslyanoi i 3-oksivalerianovoi kislot (A technique of producing heteropolymers of 3hydroxybutyric and 3-hydroxyvaleric acids). / RF Patent №. 2051968. (in Russian) № 3.

Volova T.G. (2004) Microbial polyhydroxyalkanoates - plastic material of the $21^{\text {st }}$ century (biosynthesis, properties, application). Nova Science Pub. Inc. New York, 283 p.

Vospaleniye: Rukovodstvo dlya vrachei (Inflammation: Physician's guide). Serov V.V., Paukov V.S. (eds.) (1995) Meditsina, Moscow, 629 p. (in Russian).

Zhao Q.H., Anderson J.M., Hiltner A., Lodoen G.A., Payet C.R. (1992) Theoretical analysis on cell size distribution and kinetics of foreign-body giant cell formation in vivo on polyurethane elastomers. $\mathrm{J}$ Biomed. Material Res. 26: 1019-38. 